\title{
Pollination efficiency of native and invading Africanized bees in the tropical dry forest annual plant, Kallstroemia grandiflora Torr ex Gray
}

\author{
M Osorio-Beristain, CA Domínguez*, LE Eguiarte, B Benrey \\ Instituto de Ecología, Departamento de Ecología Evolutiva, Universidad Nacional Autónoma \\ de México, AP 70-275 México City, DF 04510, Mexico
}

(Received 5 June 1996; accepted 13 September 1996)

\begin{abstract}
Summary - We compared the pollinator effectiveness of native and exotic bees on Kallstroemia grandiflora in a tropical dry forest in Mexico. Although exotic Apis mellifera transfer 2.5 times less pollen grains on a per visit basis, they visited the flowers 2.65 times more frequently than the native bee Trigona nigra. Thus, when all measures of pollinator effectiveness are combined, exotic bees appear to be as efficient pollinators as native bees.
\end{abstract}

Africanized bee / Apis mellifera / Kallstroemia / pollination efficiency / Trigona / tropical dry forest

\section{INTRODUCTION}

Flowers and pollinators have a long shared evolutionary history (Baker and Hurd, 1968). The evolution of adaptations, which enhance the efficiency of pollen transfer, the attractiveness of flowers to pollinators, and of attributes that allow animals to exploit the rewards that flowers offer, are the result of this long-term interaction. Animal pollination has also had deeper consequences, as shown by recent evidence of the higher rates of speciation in animal - versus abiotically - pollinated clades (Bawa, 1995). In this context it could be expected that, in a given habitat, animals that share a common history with plants should be better pollinators than animals of recent arrival. As has been pointed out by Roubik (1989), the introduction of African bees to the Americas is a large-scale experiment that permits the testing of these ideas. Roubik $(1978,1980,1989)$ has shown that Africanized bees may outcompete native bees when

\footnotetext{
* Correspondence and reprints

Tel: (52) 5622 9039; fax: (52) 5662 8995; e-mail: tejada@ servidor.unam.mx
} 
they forage on the same plant species. However, although it is suspected that the impact of introduced bees on the reproduction of plants could be severe (as suggested by Roubik, 1989), it remains to be evaluated (Aizen and Feinsinger, 1994a, b).

The objective of this study is to evaluate the potential effect of the recent arrival of Africanized bees on the reproduction of a native plant from a pristine tropical dry forest on the west coast of Mexico. Specifically, we made a comparison of the composition of the pollinator guild of Kallstroemia grandiflora Torr ex A Gray (Zygophyllaceae) before and after the arrival of the Africanized Apis mellifera, as well as an evaluation of several components of pollinator effectiveness of native - versus introduced - bees.

The bee fauna of Chamela before the arrival of the Africanized Apis mellifera was composed of 87 genera and 228 species (Ayala, 1988). Before 1990, the presence of European honeybees in the Chamela area was restricted to cultivated fields, and never occurred in the tropical dry forest (Ayala, 1988). The first records of Africanized bees in the Chamela area are from 1990 (R Ayala, personal communication, CA Domínguez, personal communication), as demonstrated by morphometric studies (R Ayala, personal communication). Africanized bees are now common flower visitors of many plant species of the tropical dry forest of Chamela (CA Domínguez, personal observation).

Kallstroemia grandiflora is an annual self-compatible herb with golden-orange perfect flowers (Porter, 1969; Lott, 1993). This species is associated with natural and human disturbance and is distributed in patches of variable density. The flowering season occurs from July to December. Anthesis is diurnal and each flower lasts for only one day (Porter, 1969; CA Domínguez personal observation). An average plant produces $9.3(S D=0.4, N=31)$ flowers per day. The nectariferous flowers of this species are visited by bees, wasps and butterflies (Porter, 1969). Two species of Perdita ( $P$ echinocacti and $P$ euphorbiae) have been identified as the main pollinators of $K$ grandiflora in Arizona, USA, and Sonora, Mexico (Timberlake, 1954, 1960). At Chamela, flower visitors are mainly bees, although some visits by coleopterans and lepidopterans also occur.

\section{MATERIALS AND METHODS}

This study was carried out in the Chamela Biological Station, which is located near the Pacific coast of Mexico $\left(19^{\circ} 30^{\prime} \mathrm{N}, 105^{\circ} 03^{\prime} \mathrm{W}\right)$. The predominant vegetation consists of tropical deciduous forest in the uplands and tropical semideciduous forest on arroyo sites.

The guild of pollinators of $K$ grandiflora before and after the invasion of the Africanized bees was compared by means of two different methods. First, on August 26 1989, 1 year before the arrival of the Africanized bees, we recorded the sequence of flower visitation by individual bees from their arrival at a target flower until they left the flowering patch $(N=25$ sequences, 86 flowers). In this report we use only the relative abundances and identities of the flower visitors. Second, on August 20 and 21 1994, when the Africanized bees were well established in the region, flower visitors to 46 focal flowers were recorded. These observations were done from 0800 to 1330 hours. These censuses may not reflect in the same way the specific composition of the flower visitors to $K$ grandiflora, but they give relative information on changes before and after the arrival of the Africanized bee. Both censuses were conducted at the same site during sunny days.

As a measure of the pollinator effectiveness of introduced - versus native - bees, in August 1994 we compared the number of pollen grains deposited per visit of either $A$ mellifera or the native bee Trigona (Frieseomelitta) nigra. Prior to the arrival of pollinators, 50 randomly chosen flowers of $K$ grandiflora were emasculated and bagged with paper bags. Emasculation ensures that only bee-carried pollen from other flowers was counted. Each flower was unbagged at 0800 hours and observed until it was visited by either A mellifera or T nigra. In this experiment 
only one visit per experimental flower was allowed. For each visit we also quantified the time spent on the flower (from the time at which the bee landed on the corolla until it left the flower). After pollinator departure, the stigmas were collected and the pollen grains were fixed in semipermanent basic fuchsin glycerine jelly slides (Beattie, 1971). The number of pollen grains per stigma was counted under a stereoscopic microscope.

To assess the possible effect of anther removal on the attraction and behavior of pollinators, we established a control treatment consisting of 25 additional intact (without emasculation) flowers. These flowers were bagged with paper bags early in the morning and uncovered at 0800 hours. The time spent by the first visitor, either A mellifera or T nigra, was estimated

Additionally, we estimated the total number of pollen grains a flower receives under natural conditions by collecting 46 stigmas from unmanipulated flowers after flower withering (ca 1330 hours). The stigmas were fixed and pollen grains were counted following the procedures described above.

\section{RESULTS}

\section{Floral visitors}

Our censuses indicate that the specific composition of the pollinator guild of $K$ grandiflora has changed since the arrival of the Africanized bee $A$ mellifera (table I). Melissodes tepaneca was the main flower visitor of this species in 1989 , accounting for $68 \%$ of the visits. In contrast, in $1994 M$ tepaneca accounted for only $8 \%$, while the invader bee $A$ mellifera contributed $61 \%$ of total visits. The number of visits of $T$ nigra increased from $4 \%$ in 1989 to $23 \%$ in 1994.

\section{Pollinator effectiveness}

There were 18 and 6 visits by $A$ mellifera to the 50 emasculated and 25 control flowers, respectively, and 13 and 8 by $T$ nigra

Table I. Visitors to focal flowers of Kallstroemia grandiffora before $(1989, N=25)$ and after the arrival of the Africanized Apis mellifera (1994, $N=13$ ) to the region of Chamela, Mexico.

Family Species $\quad$\begin{tabular}{cr} 
Number of bees \\
\cline { 2 - 2 }
\end{tabular}

Halictidae

$\begin{array}{lll}\text { Augochlora sp } & 3 & 0 \\ \text { Agapostemon nasutus } & 0 & 1\end{array}$

Anthophoridae

$\begin{array}{lrl}\text { Centris sp } & 2 & 0 \\ \text { Melissodes tepaneca } & 17 & 1\end{array}$

Apidae

Trigona (Frieseomelitta) nigra $\quad 1 \quad 3$

Apis mellifera

0

Vespidae
Polybia sp
1
0

Pieridae 
to the emasculated and control flowers. Flowers in both treatments were visited according to the availability of flowers in each treatment $\left(\chi 2_{(1)}=0.96, P>0.05\right)$. There was no significant effect of flower emasculation on foraging time by either A mellifera $(\bar{x}=13.2 \mathrm{~s}, S D=10.7, N=18$; $\bar{x}=8.9 \mathrm{~s}, S D=3, N=6$, in emasculated and control flowers, respectively; Mann-Whitney $U$-test $=51, P=0.87)$ or T nigra $(\bar{x}=64.5 \mathrm{~s}$, $S D=53, N=13$; and $\bar{x}=118.4 \mathrm{~s}, S D=60.6$, $N=8$; in emasculated and control flowers, respectively; Mann Whitney $U$-test $=28$, $P=0.09$ ). Therefore, the emasculation treatment did not affect the foraging behavior of either of the studied bees.

Overall, the visits of $T$ nigra to $K$ grandiflora flowers were 6.9 times longer than those of A mellifera $(\bar{x}=85.0 \mathrm{~s}, S D=59.3$, $N=21$ and $\bar{x}=12.4 \mathrm{~s}, S D=9.2, N=24$, for $T$ nigra and $A$ mellifera respectively; Mann Whitney $U$-test $=24.5, P<0.001$ ) . A single visit of $T$ nigra to emasculated flowers deposits 2.46 times more pollen grains $(\bar{x}=98.2$ pollen grains, $S D=64.3$, $N=13)$ than one of $A$ mellifera $(\bar{x}=39.9$ pollen grains, $S D=41.1, N=18$ ) (MannWhitney $U$-test $=43, P<0.01)$. The mean number of pollen grains per stigma of intact flowers was 133.1 ( $S D=60.81, N=46)$. Thus, a flower would receive its average pollen load from 1.35 visits from $T$ nigra or 3.34 visits from $A$ mellifera.

\section{DISCUSSION}

Data from 1989 and 1994 show a change in the composition of the pollinator guild of $K$ grandiflora. This change was characterized by the complete absence of four species of native flower visitors, a decrease in the abundance of the main native pollinator, $M$ tepaneca, and a corresponding increase in the abundance of $T$ nigra, formerly an uncommon native pollinator, and of $A$ nasutus and $A$ mellifera. Although this change could be a consequence of the invasion of
A mellifera, it may also be the result of random temporal fluctuations in the abundance of native bees. The available data do not allow us to discriminate between these explanations.

Our data also show that the number of pollen grains deposited per visit of the invader bee is almost 2.5 times less than that of a visit by $T$ nigra. Therefore, from the standpoint of pollinator efficiency, the foraging behavior of $A$ mellifera is less efficient per visit than that of a native species.

It has been difficult to establish a causal relationship between the arrival of invading bees, temporal fluctuations in the abundance of native bees, and their effects on plant reproduction (Roubik, personal communication). In fact, there are few studies that have been specifically designed to evaluate the effects of changes in the pollinator community on plant reproduction. For example, temporal fluctuations in the pollinator community resulted in a marked difference in the reproductive output of Calathea ovandensis (Schemske and Horvitz, 1989) and Manfreda brachystachya (Eguiarte and Búrquez, 1987, 1988). Nonetheless, studies that explicitly evaluate the impact of the introduction of Africanized bees on plant reproduction are scarce. However, it has been shown that because of its foraging behavior, the introduced bee Apis mellifera reduces the reproductive output of the self-incompatible species Prosopis nigra and Cercidium australe in small fragments of the Chaco dry forest, where this bee species is more abundant (Aizen and Feinsinger, 1994a, b).

Our estimates on pollinator effectiveness suggest that, for the self-compatible $K$ grandiflora, the effects of the arrival of $A \mathrm{mel}$ lifera may not be so dramatic. Although Africanized bees are less efficient than native bees on a per visit comparison, the efficiency disadvantage is compensated by the higher frequency of visits of $A$ mellifera. A visit of A mellifera deposits 2.46 fewer pollen grains, 
but visits are 2.65 times more frequent than those by $T$ nigra, the second most abundant bee in 1994. Hence, these results suggest that once the quantitative (the number of visits) and qualitative (the number of pollen grains deposited per visit) components of pollination effectiveness are accounted for, Africanized bees are as good pollinators as native bees. The estimation of other fitness components, such as seed-set and the performance of the progeny produced by $\mathrm{A} \mathrm{mel}$ lifera pollinated flowers, would increase our understanding of the effect of these bees on the reproduction of $K$ grandiflora.

Clearly, the results obtained for $K$ grandiflora cannot be generalized for all other plant species in the area. A thorough assessment of the effects of Africanized bees on plant reproduction requires detailed studies of plant species with contrasting reproductive systems. The outcomes of the interaction would also depend on the reward sought by bees. We suspect a stronger impact in plants with self-incompatible systems that require interplant pollen movement, and in those species pollinated by pollen-collecting bees, or by specialized pollinators (ie, Euglossapollinated flowers) (Roubik, 1989; Aizen and Feinsinger, 1994a, b; Bond, 1995).

\section{ACKNOWLEDGMENTS}

We thank the students of the field courses 1989 and 1994 of the Posgrado en Ecología del Centro de Ecología, UNAM, for field assistance. R Dirzo, C Macías, R Torres, B Burr, J Golubov, and in particular DW Roubik, and two anonymous reviewers made valuable comments to a previous version of this manuscript. We also thank the enthusiastic logistic support of $R$ Frías. $R$ Ayala kindly identified the bees and provided us with useful information.

Zusammenfassung - Bestäubungsleistung der einheimischen und der eingeschleppten afrikanisierten Bienen bei einjährigen Pflanzen der Art Kallstroemia grandiflora Torr ex Gray, im tropischen
Trockenwald. Schon lange wird immer wieder vermutet, daß die Einführung von fremdartigen Bienen einen negativen Einfluß auf die Vermehrung von einheimischen Pflanzen haben könnten. Hier untersuchen wir, welchen Einfluß3 die sich erst kürzlich in dem ursprünglichen tropischen Trockenwald an der Westküste von Mexiko verbreitenden afrikanisierten Apis mellifera auf die Bestäubung von Kallstroemia grandiflora Torr ex Gray (Zygophyllaceae) haben. Wir verglichen die Zusammensetzung der Bestäuber vor und nach dem Erscheinen der afrikanisierten Honigbiene. Wir bewerteten auch mehrere Komponenten der Bestäubungsleistung bei den einheimischen und den eingeschleppten Bienen. Unsere Daten ergeben eine Änderung in der Zusammensetzung der Bestäuber von $K$ grandiflora in den letzten fünf Jahren. Die Änderung war vor allem durch einen Rückgang des häufigsten einheimischen Bestäubers, Melissodes tepaneca, gekennzeichnet. Domzufolge gab es einen entsprechenden Anstieg in der Anzahl von zwei Arten, Trigona nigra, einem zuvor seltenen einheimischen Bestäuber, und von Apis mellifera (Tabelle I). Obwohl diese Änderung durch die Invasion von Apis mellifera hervorgerufen sein könnte, könnte dies auch auf eine zufällige zeitliche Schwankung im Vorkommen einheimischer Bienen zurückzuführen sein. Die Anzahl der Pollenkörner, die pro Blütenbesuch von der eingeschleppten Honigbiene übertragen wurde, war etwa 2,46 mal geringer als bei dem Besuch von $T$ nigra, allerdings besuchten Honigbienen die Blüten 2,65 mal häufiger. Demnach ist zwar das Sammelverhalten bei einem Besuch der Honigbiene weniger bestäubungswirksam als bei den einheimischen Arten. Aber auf Grund der quantitativen und qualitativen Komponenten (höhere Zahl der Besuche und der Gesamtzahl der Pollenkörner), die für eine Bestäubungsleistung wichtig sind, erweisen sich die afrikanisierten Bienen als den einheimischen Bienen gleichwertige Bestäuber. 
afrikanisierte Honigbiene / Apis mellifera / Kallstroemia / Bestäubungsleistung / Trigona / tropischer Trockenwald

\section{Résumé - Efficacité pollinisatrice des} abeilles indigènes et des abeilles africanisées immigrantes pour Kallstroemia grandiflora Torr ex Gray, plante annuelle de la forêt tropicale sèche. Il a été suggéré que les abeilles introduites pouvaient avoir des conséquences néfastes sur la reproduction des plantes. Nous évaluons ici l'effet potentiel de l'arrivée récente de l'abeille africanisée Apis mellifera $\mathrm{L}$ sur la pollinisation de Kallstroemia grandiflora (Zygophyllaceae) dans une forêt tropicale sèche primitive de la côte ouest du Mexique. Nous avons comparé la composition de la communauté des pollinisateurs avant et après l'arrivée des abeilles africanisées. Nous avons aussi évalué plusieurs facteurs de l'efficacité pollinisatrice des abeilles indigènes par rapport aux abeilles introduites. Nos données indiquent un changement dans la composition de la communauté des pollinisateurs durant les cinq dernières années: disparition complète de quatre abeilles indigènes, moindre abondance du principal pollinisateur Melissodes tepaneca et augmentation correspondante de Trigona nigra, pollinisateur indigène autrefois rare, et d'A mellifera (tableau I). Bien que ce changement puisse être une conséquence de l'invasion d'A mellifera, il peut être aussi le résultat de fluctuations temporelles fortuites qui affectent l'abondance des abeilles indigènes. Le nombre de grains de pollen déposés par visite par l'abeille immigrante était environ 2,46 fois plus faible que celui déposé par $T$ nigra, mais ses visites était 2,65 plus fréquentes. En conséquence, le comportement pollinisateur d'A mellifera est moins efficace que celui des espèces natives. Par contre, si l'on tient compte à la fois des facteurs quantitatif (nombre de visites) et qualitatif (nombre de grains de pollen déposés par visite), les abeilles africanisées se révèlent être d'aussi bons pollinisateurs de $K$ grandiflora que les abeilles indigènes.
Abeille africanisée / Trigona / Kallstroemia / efficacité pollinisatrice / abeille indigène / abeille introduite

\section{REFERENCES}

Aizen MA, Feinsinger P (1994a) Forest fragmentation, pollination, and plant reproduction in a Chaco dry lorest, Argentina. Ecology 75, 330-35

Aizen MA, Feinsinger P (1994b) Habitat fragmentation, native insect pollinators, and feral honcy bees in Argentine "chaco scrrano". Ecol Applic 4, 378-392

Ayala R (1988) Abejas silvestres (Hymenoptera: Apoidea) de Chamela, Jalisco, Mexico. Folia Entomol Mex 77, 395-493

Baker HG, Hurd PD (1968) Intrafloral ecology. Annu Rev Entomol 13, 385414

Bawa K (1995) Pollination, seed dispersal and diversification of angiosperms. Trends Ecol Evol 10. $311-312$

Beattie AJ (197I) A technique for the study of insectborne pollen. Pan-Pacific Entomol 47,82

Bond WJ (1995) Assessing the risk of plant extinction due to pollinator and disperser failure. In: Extinction Rates (Lawton JH. May RM. eds), Oxford University Press, Oxford, UK

Eguiarte LE, Búrquez A (1987) Reproductive ecology of Manfreda brachstachya, an iteroparous species of Agavaceae. Southwest Naturalist 32, 169-178

Equiarte LE, Búrquez. A (1988) Reducción en la fecundidad de Manfreda brachistachva (Cav) Rose, una agaváceac polinizada por murciélagos: los riesgos de la especialización en la polinización. Bol $S O C$ Bot México 48, 147-149

Lott EJ (1993) Annotated checklist of the vascular flora of the Chamela Bay region, Jalisco, Mexico. Occasional Papers of the California Academy of Sciences $148,1-60$

Porter DM (1969). The genus Kallstroemia (Zygophyllaceac). In: Contributions from the Gray Herbarium of Harvard University (Rollins RC, Foster RC, eds), Harvard University, Ma, USA

Roubik DW (1978) Competitive interactions between neotropical pollinators and Africanized honey bees. Science 201, 1030-1032

Roubik DW (1980) Foraging behavior of competing Africanized honeybees and stingless bees. Ecol ogy $61,836-845$

Roubik DW (1989) Ecology and Natural History of Tropical Bees. Cambridge University Press, Cambridge, UK

Schemske D, Horvitz CC (1989) Temporal variation in selection on a floral character. Ev'shition 43.461-465

Timberlake PH (1954) A revisional study of the bees of the genus Perdita F Smith, with special reference to the fauna of the Pacific Coast (Hymenoptera, Apoidea). I. Univ Calif Publ Entomol 9, 345-432

Timberlake PH (1960) A revisional study of the bees of the genus Perdita F Smith, with special reference to the fauna of the Pacific Coast (Hymenoptera, Apoidea). IV. Univ Calif Publ Entomol 17, 1-156 